\title{
Social Well-Being and Economic Development of Hisar City, 2010
}

\author{
Rajeev $^{1}$, Dr. Satya Prakash Kaushik ${ }^{2}$ \\ ${ }^{1}$ Research Scholar, Geography Department, Kurukshetra University, Kurukshetra \\ ${ }^{2}$ Professor, Geography Department, Kurukshetra University, Kurukshetra
}

\begin{abstract}
Social well-being of any society all over the world has cultural and technological overtones. The developed countries with their advanced technology are ahead in the level of material well-being due to the early and rapid urbanization and industrialization and change in social needs and value. But the process of industrialization and urbanization is rather slow and selective in a majority of the third world countries resulting in a very limited change in social needs. The social values change in accordance with the social needs which are governed by the micro geographical conditions, level of technology and cross-cultural assimilation. However, providing basic minimum needs such as food clothing and shelter remains a priority in India and other developing countries.
\end{abstract}

Keywords: Social Well-Bing, Social Characteristics, Economic, Field Survey, GIS, Census data

\section{Introduction}

Social development aims to promote the social and economic well-being of societies or social groups, such units are always composed of individual factors. Social development is conceived as development of the individual human being and is therefore associated with self-development. It stands for the economic and social well-being development of the community as a whole. Social development is necessary for development of a country. It deals with the study of social indicator like, age structure, age groups, sex ratio, literacy, woman empowerment, occupational structure and other indicator of social development.

\section{Statement of the Problem}

The idea of "well-being" may be contrasted with the Quality of life and social well-being of people, which takes into account not only the social problem, but also other intangible aspects that make up to the social human life such as safety, quality of life, health, Physical health, decision making, demography, cultural aspects, environmental quality and social-life etc. A social problem becomes a social problem when it affects society as whole in some way. Personal problem is not social problem. Social problems may be a personal to someone. Some major social problems are crime, gender inequality and other social problems are related to poverty, health, social inequality, injustice social insecurity, unemployment, human rights, and freedom.

\section{Objectives}

The main objective of the present study remains to;

- Assess the social and economic development of Hisar City.

\section{Research Methodology}

Present study has carried out detailed analysis of social wellbeing, economic, health and infrastructural aspect of the population. The study is based on field survey, secondary data and GIS related data.

\subsection{Data base}

Information such as population details of each ward, ward wise map of study area and district gazetteer were collected from municipal committee Hisar and statistical department of Hisar. The digitized map of study area and information map (Hisar constituency) were collected from Haryana Space Application Center (HARSAC) Hisar. Explanatory data for the purpose of comparison of Hisar with Haryana and India has been taken from statistical abstract of Haryana and India, 2001 and provisional population tables, census of India, 2011. The study is largely based on field survey. The questionnaire consists of data related to social, economic, health, and demography and infrastructure aspects.

\subsection{Sample Selection}

The study is based on 477 samples which is one percent of the total households of the study area. Sample households were selected in proportion to ward population. Samples were collected randomly within each ward. The author has also conducted personal interviews of the Hisar's households. The author personally went to each ward of study area and put questions related to household 's information and get information about social and economic development of urban area.

\subsection{Data processing}

The collected data is tabulated and processed with the help of simple statistical techniques such as percentage and ratio. Level of social, economic, and infrastructural development is worked out with the help of composite Z-score. Similarly, population characteristics like age and sex composition of population, literacy rate, per capita income, were calculated and analyses with the help of simple statistical techniques. The processed data is cartographically represented by maps prepared in Arc GIS 9.3.1, Desktop editor and Arc Info. SPSS 12.1 is also used for calculation of standard deviation and mean. AutoCAD map 2000i is also used for map digitization. 


\section{International Journal of Science and Research (IJSR) \\ ISSN (Online): 2319-7064 \\ Index Copernicus Value (2013): 6.14 | Impact Factor (2014): 5.611}

\section{Study Area}

Hisar city located at $29^{0} 10^{\text {ee }}$ north latitude and $75^{\circ} 45^{\text {ee }}$ east longitude, is one of the important and fast growing urban center of Haryana. Hisar has grown to a vital position on the urban map of Haryana. It has come up because of its location factors. Its location is such that for any development away from grand trunk road and railway line. Hisar drawn attention city of Faridbad, Gurgoan and Rohtak have different reasons for there growth where as Hisar city is growing entirely on its potential to grow and its nodality in the region.

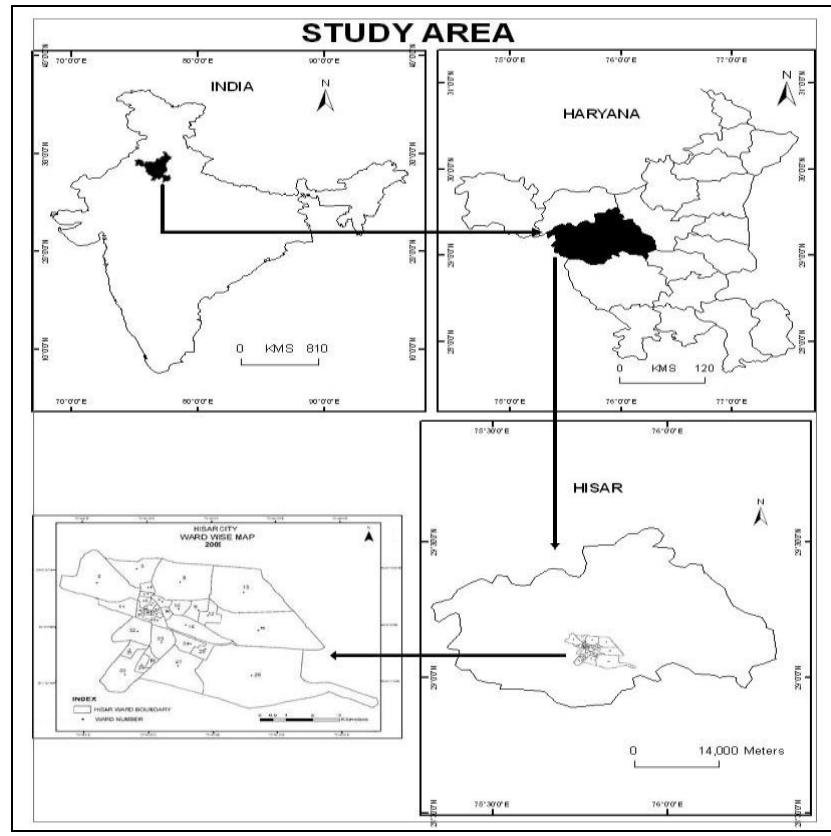

Figure 1

\subsection{Origin of the Name of the Town}

The city of Hisar was founded by a Muslim ruler, Firozshah Tughlaq in 1354 A.D. „Hisare is an Arabic word which means ,Fort". The city, which we know today as „Hisare, was originally called „Hisar Firoza (also Hisar-e-Firoza) or in other words the ,Fort of Firoz ${ }^{\text {ee }}$. But as the days rolled by, the word ,Firoza ${ }^{e c}$ was dropped from its original name.

It gained importance in early sixties when agriculture university, was setup as an extension of the Punjab Agriculture University, Ludhiana. Ever, since, the government's positive polices and good behaviors have played a vital role in the economic development of the city.The industrial policy of the government has attracted large number of entire preneurs and has resulted into the industrialization in around the city the construction of a new judicial complex and district administrative complex, shifting of Haryana state electricity board offices, setting up of cantonment and development a new residential sectors have made this city a strong growth center in the region in Haryana.

\subsection{Sex Ratio}

Sex ratio in India is calculated in terms of number of females per thousand males. Sex ratio is highly imbalanced in Indian states context (Chandana, 2000). The state like Haryana is in serious conditions in this regard. Sex ratio in Haryana had declined continuously since 1981 and was recorded its lowest figure (861) in 2001. It was the lowest amongst major states of India. Average sex ratio in India was 933 females per thousands males in 2001. The situation is good in 2011 when it increased to 940 females per thousands males.

Sex ratio in Hisar had improved to 849 females per 1000 males in 2011 as compare to census 2001 which was 831 females per 1000 males. It is a good sign for improvement in sex ratio in Hisar. It happened due to some social programme organized by health department (Census of India, 2011).

Table 1: Hisar: Ward Wise Sex Ratio, 2010

\begin{tabular}{|l|l|l|l|}
\hline Ward No. & Female per 1000 males & Ward No. & Female per 1000 \\
\hline 1. & 1300 & 17. & 809 \\
\hline 2. & 1151 & 18. & 687 \\
\hline 3. & 909 & 19. & 1375 \\
\hline 4. & 1167 & 20. & 722 \\
\hline 5. & 857 & 21. & 789 \\
\hline 6. & 467 & 22. & 1033 \\
\hline 7. & 889 & 23. & 846 \\
\hline 8. & 967 & 24. & 754 \\
\hline 9. & 821 & 25. & 625 \\
\hline 10. & 867 & 26. & 881 \\
\hline 11. & 543 & 27. & 667 \\
\hline 12. & 632 & 28. & 750 \\
\hline 13 & 963 & 29. & 785 \\
\hline 14. & 904 & 30. & 870 \\
\hline 15. & 705 & 31. & 724 \\
\hline 16. & 1000 & 32. & 648 \\
\hline Total & & 835 \\
\hline
\end{tabular}

Source: Hisar: Field Survey, 2010

Fig .2 shows that average sex ratio in Hisar is 835 females per thousands males. It is low as compare to state sex ratio (861females per thousand males). So Hisar has measurable condition of sex ratio as compare to sex ratio of state. The ward wise picture of sex ratio shows that ward no. 1, $2,4,8,16,19$ and 21 are in the better position as compared to rest of wards of Hisar. Ward no. 1 has the highest figure and ward No.6 has the lowest figure among all the wards. Businessmen and high profile people live in ward no. 6,11 , 12 and 20, they do not prefer more children and also aware about misuse of modern technology and they afford much to pay . 


\section{International Journal of Science and Research (IJSR) \\ ISSN (Online): 2319-7064}

Index Copernicus Value (2013): 6.14 | Impact Factor (2014): 5.611

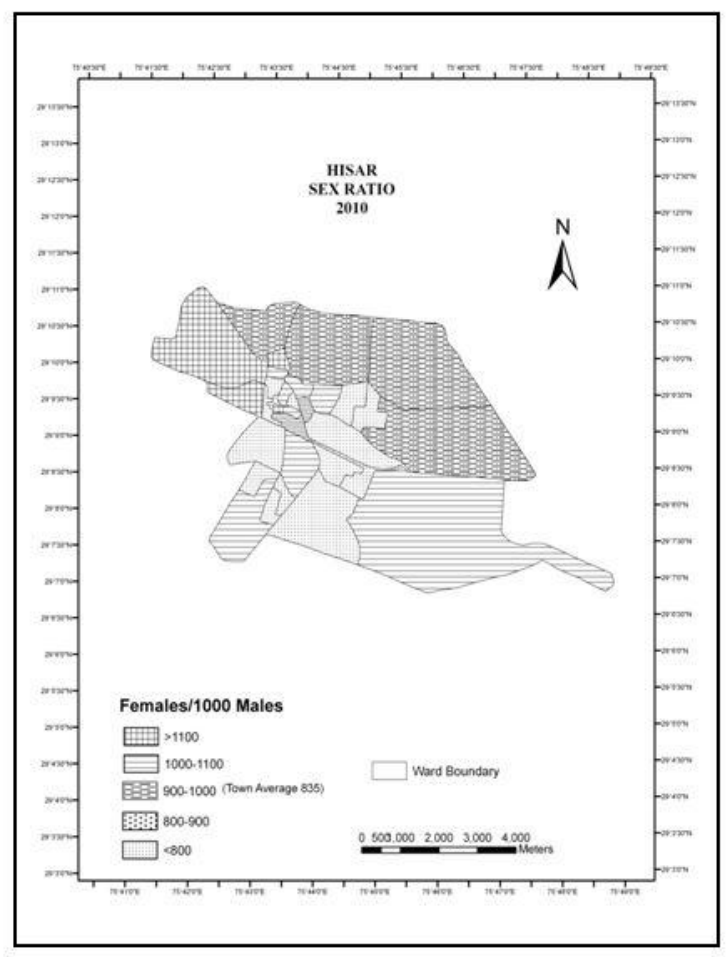

Figure 2

Table 2: Hisar: Sex Ratio by Age Group, 2010

\begin{tabular}{|c|c|}
\hline Age Group & Females per 1000 males \\
\hline $0-4$ & 534 \\
\hline $5-9$ & 814 \\
\hline $10-14$ & 636 \\
\hline $15-19$ & 807 \\
\hline $20-24$ & 914 \\
\hline $25-29$ & 1214 \\
\hline $30-34$ & 740 \\
\hline $35-39$ & 988 \\
\hline $40-44$ & 1188 \\
\hline $45-49$ & 759 \\
\hline $50-54$ & 820 \\
\hline $55-59$ & 618 \\
\hline $60-64$ & 702 \\
\hline $65-69$ & 562 \\
\hline $70-74$ & 1500 \\
\hline$>75$ & 750 \\
\hline
\end{tabular}

Source: Field Survey of Hisar, 2010

Table 2 shows that the average sex ratio in the age group of 25 to 29,40 to 44 and 70 to 74 are in better position. On the other hand $0-4$ and 10-14 age groups have measurable condition in sex ratio as compare to average sex ratio of Hisar. The point is that the sex ratio of $0-4$ age group is low as compare to sex ratio of Haryana and Hisar.

\subsubsection{Literacy}

The concept of literacy varies from country to country. The population commission of United Nations considers the ability to both read and write a simple message with understanding in any language a sufficient basis for classifying persons a literate. The Indian census had adopted this definition (Chandana, 2008). In India also the definition of literacy has under gone changes. Since 1991 census literacy rate in India are calculated as follows:-
Effective literacy rate $=$ Total literate of an area / population of above 6 years age of that area x 100 (Chandana, 2008). Literacy rate in the study area is calculated as follows: Minimum one class passed(aged7 and above) Population (aged 7 and above)

Table 3 Hisar: Class wise Literacy Rate (Aged 7 and above), 2010

(In Percent)

\begin{tabular}{|c|c|c|c|}
\hline & Persons & Males & Females \\
\hline \multicolumn{4}{|c|}{ Social Group } \\
\hline Low & 84.88 & 89.69 & 79.45 \\
\hline Middle & 87.25 & 92.41 & 81.23 \\
\hline High & 92.09 & 96.13 & 87.30 \\
\hline Total & 88.46 & 93.13 & 83.01 \\
\hline \multicolumn{4}{|c|}{ Income group } \\
\hline$<2300$ & 93.30 & 100.00 & 88.88 \\
\hline $2300-4600$ & 75.78 & 85.71 & 65.22 \\
\hline $4600-6900$ & 84.50 & 88.21 & 80.60 \\
\hline$>6900$ & 90.08 & 94.65 & 84.58 \\
\hline Total & 88.46 & 93.13 & 83.01 \\
\hline \multicolumn{4}{|c|}{ Source: Field Survey of Hisar, 2010 }
\end{tabular}

Table 3 shows that the total literacy rate is 88.46 percent. Male literacy rate is higher than female literacy rate. Male literacy rate is 93.13 percent and female literacy rate is 83.01 percent. Literacy rate is quite high in the high social group as compare to middle and low social groups. Males and females literacy is also high in high social group as compare to middle and low groups. Literacy rate is 84.88 percent in low social group, which increased to 87.25 in middle social group and 92.09 percent in high social group.

\subsubsection{Role of Women}

The studies have revealed an increasing number of cases where the role of woman in family decision making is primary or at least shared equally with the man. There role in controlling family finances, family planning, political issues and other family issues and making decisions as to where the various expenses should be incurred has come to forefront with researches depicting 37 percent men dealing with the same individually, 28 percent with their wives and 30 percent solely controlled by women. Poverty is playing an important role in family decision making. Poverty is usually measured as either absolute or relative poverty. Absolute poverty refers to set standard which is consistent over time and between countries. The World Bank defines extreme poverty as living on less than US $\$ 1.25$ purchasing power parity (ppp) and moderate poverty as less than $\$ 2$ a day. It estimates that in 20011.1 billion people had consumption levels below $\$ 1$ a day and 2.7 billion lived on less than $\$ 2$ a day (World Bank, 2001). Empowering woman has helped some countries increase and sustain economic development when given more rights and opportunities. Women begin to receive more education, thus increasing the overall human capital of the country, when given more influence women seem to act more responsible in helping people in the family or village and when better educated and more in control of their lives, women are more successful in bringing down rapid population growth because they have more say in family planning. 


\section{International Journal of Science and Research (IJSR) \\ ISSN (Online): 2319-7064 \\ Index Copernicus Value (2013): 6.14 | Impact Factor (2014): 5.611}

Table 4 Hisar: Level of Woman Participation in Families' Decisions

\begin{tabular}{|c|c|c|c|}
\hline & Political View & Female Feticide & Family Planning \\
\hline Social Group \\
\hline Low & 63.86 & 40.34 & 58.82 \\
\hline Middle & 68.36 & 50.85 & 72.32 \\
\hline High & 74.03 & 60.77 & 82.87 \\
\hline Total & 69.39 & 51.99 & 72.96 \\
\hline Income Group \\
\hline$<2300$ & 50.00 & 25.00 & 75.00 \\
\hline $2300-4600$ & 63.64 & 54.55 & 45.45 \\
\hline $4600-6900$ & 50.00 & 30.21 & 47.92 \\
\hline$>6900$ & 75.21 & 58.03 & 81.41 \\
\hline Total & 69.39 & 51.99 & 72.96 \\
\hline
\end{tabular}

Table 4 reveals that 69.39 percent women are playing an important role in making political decisions. High social group women are much interested in political decisions as compare to low and middle social group. Same situation is found in case of female foeticide. High social group females are much aware about female foeticide as compare to low and middle social group. About 51.99 percent women have knowledge of female foeticide according to field survey. On the other hand 72.96 percent women are worried about family planning. High social group women are playing main role in family planning decisions. There are marginally difference between high social group and middle social group women. But low social group women are not interested in family planning as compare to high and middle social group women. About 58.82 percent women are taking decisions of family planning in low social group.

Similarly, very low income group women are not much interested in the decisions of political issues as compare to middle and high income group women. About 75.21 percent women"s of high income group are playing important role in political issues of families. Very low income group women do not have much knowledge about female foeticide as compare to high and middle income group women. About 25 percent women of very low income group have knowledge about female foeticide.

Female foeticide cases are more prevalent in high income group families as compare to low and middle income group families because women have much knowledge about female foeticide of these groups, and also aware about modern technology. Health department also organized social programme like women empowerment, save girl child and social development of women related programme.

High income group familyes women playing important role in family planning decisions as compare to low and middle income group families. About 81.41 percent women of high income group family worried about family planning decisions. Low income group women have little knowledge about family planning.

\subsection{Economic Development}

Household is usually a group of persons who normally live together and take their meals from a common kitchen unless the exigencies of work prevent any of them from doing. Persons in a household may be related or unrelated or a mix of both. However, if a group of unrelated persons live in a census house but do not take their meals from the common kitchen, then they are not constituent of a common household (Census of India, 2001).

Table 5: Hisar: Distribution of Household by Economic and Social Status (In Percent)

\begin{tabular}{|c|c|}
\hline \multicolumn{2}{|c|}{ Social Group } \\
\hline Low & 24.95 \\
\hline Medium & 37.11 \\
\hline High & 37.94 \\
\hline \multicolumn{2}{|c|}{ Income Group } \\
\hline $2300-4600$ & 0.84 \\
\hline $4600-6900$ & 4.61 \\
\hline$>6900$ & 20.13 \\
\hline Total & 74.42 \\
\hline
\end{tabular}

Source: Field Survey of Hisar, 2010

Table 5 shows that about one forth percent of total households are belong to low social group. About 37.11 percent households are belonging to medium social group. There is marginally difference between medium and high social group of households.

Proportion of households are belong to high income group (>74 percent households). Only 4.61 percent households are belong to low income group and 20.13 percent in medium income group. So proportion of households are belong to high income group because Hisar is an industrial and fast growing town and job opportunity is high and per capita income is also good.

\subsubsection{Age Structure}

There are many determinants of age compositions like health care determinants or vital determinants, but there are three basic determinants of age compositions of a population.

Age Groups:

Table 6: Hisar: Age Structure, 2010

(In percent)

\begin{tabular}{|l|c|c|c|c|}
\hline Age Group & $\mathbf{0 - 1 4}$ & $\mathbf{1 5 - 4 4}$ & $\mathbf{4 5 - 5 9}$ & $\mathbf{5 9}$ \\
\hline Social Group & 29.36 & 55.46 & 11.92 & 3.26 \\
\hline Low & 17.62 & 56.68 & 16.59 & 9.11 \\
\hline Medium & 1989 & 57.27 & 15.23 & 7.61 \\
\hline High & 21.52 & 56.59 & 14.86 & 7.03 \\
\hline Total \\
\hline \multicolumn{5}{|l|}{} \\
\hline Income Group 2300 & 31.25 & 43.75 & 25.00 & - \\
\hline $2300-4600$ & 25.00 & 59.62 & 9.62 & 5.76 \\
\hline $4600-6900$ & 30.94 & 52.94 & 10.02 & 6.10 \\
\hline$>6900$ & 18.80 & 57.46 & 16.34 & 7.40 \\
\hline Total & 21.52 & 56.59 & 14.86 & 7.03 \\
\hline
\end{tabular}

Source: Field Survey of Hisar, 2010

Table 6 shows the relationship of age structure with social and income level. Young population consists of about 21.52 percent of the total population. The active population in the age group of 15 to 44 and 45 to 59 is about 56.59 and 14.86 percent of the total population respectively. Old and aged persons are seven percent of the total population of the study area. 


\section{International Journal of Science and Research (IJSR) \\ ISSN (Online): 2319-7064}

Index Copernicus Value (2013): 6.14 | Impact Factor (2014): 5.611

Share of young population is quite high in the low social group as compare to middle and high social groups. Proportion of aged population is high in the medium social group as compare to low and high social group. The active population is marginally low in the low social group as compare to middle and high social group.

Similarly, low income groups have higher proportion of young population as compare to high income groups. Low income groups have lower proportion of active population as compare to high income groups. The poor and low income group people being illiterate preferred large number of children by increasing the proportion of young population as children are considered asset to the family.

\subsubsection{Occupational Structure of Household}

The percentage of population that is economically active is an important index of development. The distribution of the population according to different types of occupation is referred to as the occupational structure. An enormous variety of occupations are found in any country.

Occupations are generally classified as primary, secondary, and tertiary.

Primary activities include agriculture, animal husbandry, forestry, fishing, mining and quarrying etc.

Secondary activities include manufacturing industry, building and construction work etc.

Tertiary activities include transport, communications, commerce, administration and other services (Census, 2011).

Table 7 Hisar: Occupational Structure of Household

\begin{tabular}{|ll|c|c|c|}
\hline \multicolumn{2}{|c|}{ Place } & $\begin{array}{c}\text { Primary } \\
\text { activities }\end{array}$ & $\begin{array}{c}\text { Secondary } \\
\text { activities }\end{array}$ & $\begin{array}{c}\text { Tertiary } \\
\text { activities }\end{array}$ \\
\hline India & $\mathrm{X}^{1}$ & 19.65 & 13.25 & 64.10 \\
\hline Haryana & $\mathrm{X}^{2}$ & 29.17 & 28.10 & 42.83 \\
\hline Hisar & $\mathrm{X}^{3}$ & 7.25 & 9.80 & 82.95 \\
\hline
\end{tabular}

Sources:

$\mathrm{X}^{1}$ National Sample Survey 2003-2004

$\mathrm{X}^{2}$ Statistical Abstract of Haryana, 2004-2005

$\mathrm{X}^{3}$ Field Survey of Hisar, 2010

Figure 3 shows that 7.25 percent people are involved in primary activities which increased to 9.80 percent in secondary activities and 82.95 percent in tertiary activities.

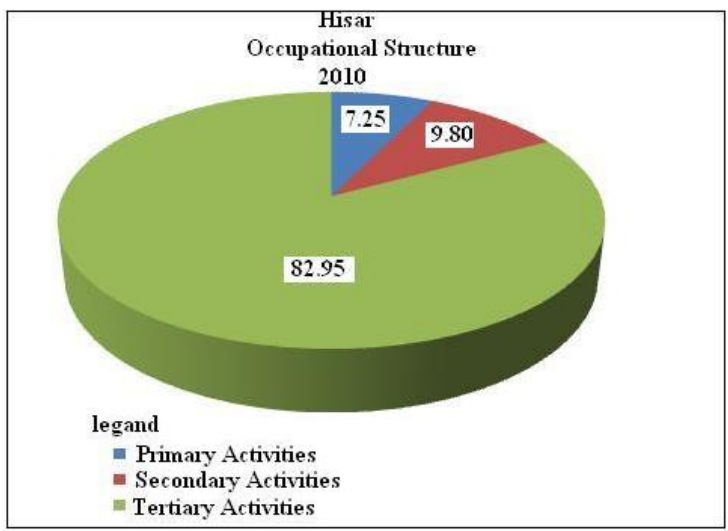

Figure 3

\subsubsection{Work Participation Rate}

Work is defined as participation in any economically productive activity with or without compensation, wages or profit. Such participation may be physical or mental in nature. Work involves not only actual work but also includes effective supervision and direction of work. It even includes part time help or unpaid work on farm, family enterprise or in any other economic activity. All persons engaged in 'work' as defined above are workers. Persons who are engaged in cultivation or milk production even solely for domestic consumption are also treated as workers (Census of India, 2001).

"Work participation rate is defined as the percentage of total workers (main and marginal) to total population".

Total Workers (Main+Marginal)

Work Participation Rate

$$
\text { Total Population }
$$

Table 8 Hisar: Work Participation Rate

\begin{tabular}{|c|c|c|c|}
\hline Place & India & Haryana & Hisar \\
\hline Work participation rate & 51.93 & 50.49 & 55.38 \\
\hline
\end{tabular}

Source: Field Survey of Hisar, 2010

Table 8 shows that the work participation rate of Hisar is 55.38 percent. It is high as compare to state work participation rate to national level (51.93percent), because Hisar is an industrial and fast growing town of Haryana which offer jobs in secondary and territory activities.

\subsubsection{Dependency Ratio}

Dependency ratio is defined as the ratio of the population below age of 15 years and those aged 60 years and above, per 100 of the population aged $15-59$ years.

Dependency Ratio $=674 / 1858$ X $100=36.28$

\subsubsection{Per Capita Income}

The world has deep poverty amid plenty of the world's more than 6.7 billion people, about 3.4 billion (almost half) live a less than \$ 2 a day and1.6 billion (one fifth) live on less than $\$ 1$ a day, with estimated $46 \%$ living in south Asia (World Bank Report, 2004-2005). According to an estimate about more than half billion people are living in towns and cities of the world. According to an estimate about 3.3 billion people are living in towns and cities of developing countries and this figure could be approach 5 billion by the year 2030 . Per capita income of India is 1081 Rupees. (World Bank Report, 2008-2009).

Per capita income in the study area is calculated as follow:

Per capita income $=\frac{\text { Totalincome of the ward }}{\text { Total population of the ward }}$

\subsubsection{Composite Index of Social and Economic Development}

Table 8 shows that the ward wise picture of sex ratio shows that ward no. 1, 2,4,8,16,19 and 21 are in the better position as compared to average sex ratio of Hisar. Ward No. 1 has the highest figure and ward No.6 has the lowest figure among all wards. High literacy rate wards are 1,4,5,8, 10,12,25, 


\section{International Journal of Science and Research (IJSR) \\ ISSN (Online): 2319-7064}

Index Copernicus Value (2013): 6.14 | Impact Factor (2014): 5.611

Table 8 Hisar: Composite Index of Social and Economic Development, 2010

\begin{tabular}{|c|c|c|c|c|c|c|c|}
\hline $\begin{array}{c}\text { Ward } \\
\text { No. }\end{array}$ & $\begin{array}{c}\text { Sex } \\
\text { Ratio }\end{array}$ & Literacy & $\begin{array}{c}\text { Per Capita } \\
\text { income }\end{array}$ & \begin{tabular}{c|} 
Family \\
planning
\end{tabular} & $\begin{array}{c}\text { Female } \\
\text { Foeticide }\end{array}$ & $\begin{array}{c}\text { Political } \\
\text { View }\end{array}$ & $\begin{array}{c}\text { Composite } \\
\text { Index }\end{array}$ \\
\hline 1. & 1300 & 90.91 & 1300 & 70.00 & 60.00 & 80.00 & 2.07 \\
\hline 2. & 1151 & 89.70 & 1514 & 80.00 & 46.67 & 86.67 & 1.95 \\
\hline 3. & 909 & 84.42 & 1540 & 72.22 & 50.00 & 83.33 & 0.27 \\
\hline 4. & 1167 & 95.65 & 1667 & 100.00 & 80.00 & 80.00 & 6.13 \\
\hline 5. & 857 & 100.00 & 1804 & 83.33 & 66.67 & 83.33 & 4.00 \\
\hline 6. & 467 & \begin{tabular}{|l|}
68.18 \\
\end{tabular} & 1819 & 40.00 & 40.00 & 100.00 & -3.53 \\
\hline 7. & 889 & 83.33 & 1248 & 80.00 & 60.00 & 60.00 & -0.94 \\
\hline 8. & 967 & 94.12 & 1423 & 63.64 & 81.82 & 90.91 & 3.22 \\
\hline 9. & 821 & \begin{tabular}{|l|}
77.55 \\
\end{tabular} & 1512 & 30.00 & 40.00 & 40.00 & -5.95 \\
\hline 10. & 867 & \begin{tabular}{|l|}
93.42 \\
\end{tabular} & 1660 & 89.28 & 42.85 & 39.29 & -0.72 \\
\hline 11. & 543 & \begin{tabular}{|l|}
79.17 \\
\end{tabular} & 1619 & 100.00 & 45.45 & 63.64 & -1.34 \\
\hline 12. & 632 & 91.80 & 1607 & 53.85 & 46.65 & 46.15 & -3.18 \\
\hline 13 & 963 & 80.00 & 1473 & 71.43 & 52.38 & 57.14 & -1.34 \\
\hline 14. & 904 & 79.23 & 1360 & 59.26 & 44.44 & 77.78 & -2.14 \\
\hline 15. & 705 & 84.21 & 1474 & 70.59 & 52.94 & 47.06 & -2.57 \\
\hline 16. & 1000 & \begin{tabular}{|l}
84.62 \\
\end{tabular} & 1676 & 77.78 & 55.56 & 66.67 & 0.91 \\
\hline 17. & 809 & 88.89 & 1362 & 71.43 & 71.43 & 85.71 & 1.30 \\
\hline 18. & 687 & \begin{tabular}{|l|}
79.31 \\
\end{tabular} & 1615 & 50.00 & 50.00 & 33.33 & -4.60 \\
\hline 19. & 1375 & 81.58 & 1116 & 50.00 & 33.33 & 50.00 & -3.55 \\
\hline 20. & 722 & \begin{tabular}{|l}
88.46 \\
\end{tabular} & 1181 & 80.00 & 80.00 & 80.00 & 1.10 \\
\hline 21. & 789 & \begin{tabular}{|l}
83.33 \\
\end{tabular} & 1515 & 57.14 & 57.14 & 71.42 & -1.28 \\
\hline 22. & 1033 & \begin{tabular}{|l}
88.14 \\
\end{tabular} & 1726 & 92.86 & 78.57 & 92.85 & 5.33 \\
\hline 23. & 846 & 82.22 & 1527 & 50.00 & 60.00 & 100.00 & 0.24 \\
\hline 24. & 754 & 89.90 & 1335 & 90.44 & 72.22 & 94.44 & 2.58 \\
\hline 25. & 625 & 96.63 & 1495 & 100.00 & 64.76 & 70.59 & 1.82 \\
\hline 26. & 881 & \begin{tabular}{|l}
87.65 \\
\end{tabular} & 1613 & 81.67 & 40.00 & 58.33 & -0.89 \\
\hline 27. & 667 & 96.12 & 1660 & 50.00 & 54.54 & 95.45 & 0.47 \\
\hline 28. & 750 & \begin{tabular}{|l}
94.55 \\
\end{tabular} & 1512 & 72.73 & 72.73 & 81.82 & 1.98 \\
\hline 29. & 785 & \begin{tabular}{|l|l|}
93.75 \\
\end{tabular} & 1578 & 80.00 & 50.00 & 60.00 & -0.16 \\
\hline 30. & 870 & 95.63 & 1583 & 58.00 & 44.00 & 72.00 & -0.58 \\
\hline 31. & 724 & \begin{tabular}{|l}
85.71 \\
\end{tabular} & 1488 & 90.00 & 50.00 & 80.00 & 0.20 \\
\hline 32. & 648 & 94.34 & 1817 & 92.31 & 38.46 & 46.15 & -0.83 \\
\hline
\end{tabular}

Source: Field Survey of Hisar, 2010

$27,28,29,30$ and 32 . A very low literacy ward is 6 . Low per capita income wards are 7,19 and 20. Moderate per capita income wards are $1,18,13,14,15,17$ and 24 . High per capita income wards are $2,3,4,5,6,9,10,11,12,16,18,21,22,23$ ,26,27,28,29 and 30. Women of wards no. $6,12,14,18,19$ ,21, 23, 27 and 30 are low knowledge about family planning. Women of wards no. 2, 4, 5,7,10, 11, 20, 22, 24, 25, 26, 29, 31 and 32 are more Knowledge about family planning. Women of ward no. 1,3,13,15,16,17 and 28 are low knowledge about family planning as compare to above wards. This table also shows the decision of family.

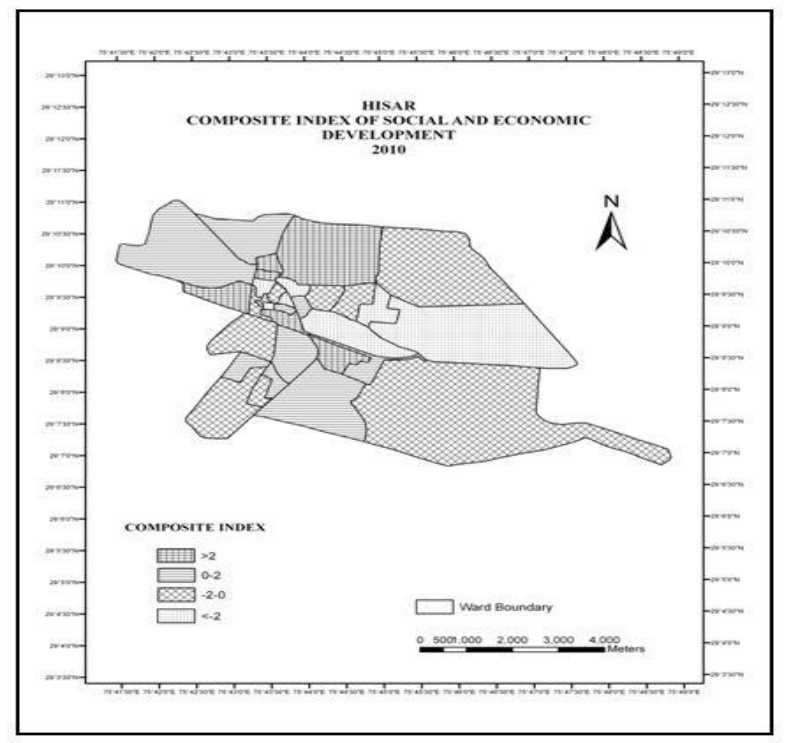

Figure 4
Figure 4 shows that very low developed wards are $6,9,10$, $12,14,15,18$ and 19. Low developed wards are 7, 10, 11, 13, $21,26,29,30$, and 32. High developed wards are 2, $3,16,17,20,23,25,27,28$ and 31 . Very high developed wards are 1, 4 5,8,22 and 24.Mainly high income group or high social group people are belonged to above these wards. Income is positively related to development of particular area.

\section{Conclusion}

The present study shows that the low social and income group have higher proportion of young population as compare to high income groups. The poor and low income group people being illiterate preferred large number of children by increasing the proportion of young population as children are considered asset to the family. Sex ratio in Hisar is 835 females per thousands males. Sex ratio is low in ward no. $6,11,12$ and 20. Businessmen and high profile people live in these wards. They have not preferred large number of children and also aware about misuse of modern technology. Moreover, they can afford to pay for sex determination and sex specific abortion.

Literacy rate of Hisar city is good. Only ward no. 6 has very low literacy of 68.18 percent. Hisar has an average literacy rate of 89.46 percent which is higher than the national average. Participation rate is higher due to increase of literacy rate in this city. Work participation rate is 55.38 percent in the Hisar urban agglomeration. With the development of industrial units, the job opportunities also increased, because of good facilities and increasing jobs, people migrated from rural area to urban area which has accelerated urbanization. Overall, social and economic development is low in ward no. 6,10 and 18, because these are old part of the city and are highly congested.

In Hisar city the living standards of people were satisfactory. Only some wards such as 3, 9, 10, 11, 12, 19, 24 and 31 shows that the living standards of people were moderate. The high income and high social group women play important role in family decisions making. So their role in controlling family finance, family planning, and political issues and other family issues is higher than low social and income groups women. High income groups women are more interested in political issues as compare to low social and income groups women, so income is positively related to women role in family decisions making. Proportions of households of high income group dominate in the study area (76.31 percent). Only 4.61 percent of households belong to low income group. Proportion of people involved in tertiary activity is more than 74 percent. Only 7.25 percent people are involved in primary activities.

The overall development shows that ward no. $6,9,12,14,15,18$ and 19 are very low developed. Low developed wards are $7,10,11,13,24,26,29,30$, and 32 . High developed wards are 2,3,16,17,20,23,25,27,28 and 31 . Very high developed wards are 1, 4, 5,8,22 and 24. Mainly high income group or high social group people are belonged to above these wards. Income is positively related to 


\section{International Journal of Science and Research (IJSR) \\ ISSN (Online): 2319-7064}

Index Copernicus Value (2013): 6.14 | Impact Factor (2014): 5.611

development of particular area. These wards are dominated by the businessmen and servicemen, so per capita income is high and development of these wards is also high.

\section{References}

[1] Bhargawa, A., (1989), "Globalization, Literacy Levels and Economic Development," In the Poor Under Globalization in Africa, Asia and Latin America, Edited By Nissanke and Thorbecke, E., Oxford University Press, USA.

[2] Bishnoi, S., (2000), "Rural Settlements Analysis of Village Sadal Pur, District Hisar," Un- published M.Phil Dissertation, Department of Geography, Kurukshetra University, Kurukshetra.

[3] Cameron, K., (2001), "Well-Being and Occupational Health in the $21^{\text {st }}$ Centaury Work Place," Journal of Occupational and Organizational Psychology, Vol. 1, No.1, pp- 489-509.

[4] Chen, L.C. and A.K., (2007), "Turnaround in China"s Health Policies?" Indian Journal of Human Development, Vol. I, No. 1, pp. 163-165.

[5] Gayatri, K., (2004), “Urban Poverty- Issues ,Polices and Action," In Urban Poverty in India edited by Sandhu, R.S., Uppal Publishing House, New Delhi, pp. 53,54.

[6] Kaushik, S.P., (2001), "Spatial and Structural Pattern of Urban Population and Its Social and Economic Attributes in Haryana", Indian Journal of Geography and Environment, Vol. 8 and 9 : 2003-2004, Vidya Sagar University ,Medinipur West Bengal , India, pp. 52-63.

[7] Premi, M.K., (2006), "Social Demography: A Systematic Exposition," Jawahar Publishers and Distributors, New Delhi.

\section{Internet}

[8] Larson, J. S. (1993), "The Measurement of Social Wellbeing," Journal of Social Indicator Research, Vol. 28, No. 3, pp. 285-296, Published by Personal Social Services Research Unit Bulletin and Publication, UK. http://www.google.co.in/m?q=

larson+england $+1998+$ on + social+well+being/+

Munasinghe (2000), + Social + well -being + and +urbanization $=+$ development/ + htmlpadg?/+home.

[9] Kulkarni, K.M., (1998), "Geographical Patterns of Social-Wellbeing: With Special Reference to Gujrat," New Delhi Concept Publishing Company, New Delhi, pp. 3-24., http://books.google.co.in/books?id=tI8yMTBvKQC\&pg $=$ PA45\&dq $=$ Problem + of + local + social + well + Being.. df

[10]Definition of Social Well-being, http://data.worldbank.org/country/india.

Government Publications:

[11] Census of India (2007-08): District Census Hand Books, Hisar, Government of Haryana, pp. 8-35.

[12]Haryana Government Gazetteer (1987): District Gazetteer of Hisar, January 19, 1987, Government of Haryana, pp. 6-25.

[13] Statistical Abstract Haryana (2003-04): Department of Economic and Statistical, Government of Haryana, pp. 459-465.

\section{Government Offices}

[14]HARSAC ( Haryana Space Application Center), Haryana Agriculture University Hisar,

[15]District Statistical Office , Mini Secretariat, Hisar, Haryana

[16] Municipal Committee ,Hisar

[17]Department of Town and Country Planning, Hisar, Haryana

\section{Author Profile}

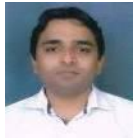

Rajeev. did M.Phil. in Geography from Kurukshetra University in 20012 and P.G. Diploma in Remote Sensing and GIS from Uttarakhand Open University in Uttarakhand, 2015, and currently I am working as a JRF/Project Fellow in HARSAC, Department of Science and Technology, CCS, HAU Campus, Hisar.

Dr. Satya Prakash Kaushik - M.A., M.Phil \& Ph.D Jawaharlal Nehru University, Delhi and Currently working as Professor in Department of Geography, Kurukshetra University in Kurukshetra, India 